\title{
An international study on starting tumour necrosis factor-blocking agents in ankylosing spondylitis
}

\author{
T Pham, R Landewé, S van der Linden, M Dougados, J Sieper, J Braun, J Davis, \\ M Rudwaleit, E Collantes, R Burgos-Vargas, J Edmonds, I Olivieri, I van der Horst- \\ Bruinsma, H Mielants, M Stone, P Emery, D van der Heijde
}

See end of article for authors' affiliations

Correspondence to: T Pham, Department of Rheumatology, AixMarseille II University, Conception Hospital, 147 bd Baille, 13005

Marseille, France; thao.pham@ap-hm.fr

Accepted 31 January 2006 Published Online First 7 February 2006

\begin{abstract}
Objectives: To determine the type and proportion of patients with ankylosing spondylitis who rheumatologists consider to be candidates for treatment with tumour necrosis factor (TNF)-blocking agents, and to what extent this is in agreement with the ASsessment in Ankylosing Spondylitis (ASAS) international working group recommendations on initiation of treatment with anti-TNF agents.

Methods: Participants were rheumatologists from 10 different countries, who were considered to be experts in treating patients with ankylosing spondylitis and in the use of anti-TNF treatment, but were unaware of the ASAS recommendations (unpublished at the time of study in 2003). The first 10 consecutive patients with ankylosing spondylitis seen by the rheumatologist were evaluated as to whether the patient was a candidate for anti-TNF treatment. Thereafter, a metrologist assessed the patient for disease activity and severity, and collected data on demographics and treatment.

Results: Complete data were available for 1207 of the 1284 patients and were used for analysis. Overall, the rheumatologists indicated that they would initiate TNF-blocking agents in $49.3 \%$ of patients, ranging from $37.2 \%$ patients in Canada to $78.3 \%$ in Australia. These candidates had higher disease activity, higher levels of acute-phase reactants, worse spinal mobility, worse function, more often hip involvement and a higher prevalence of sick leave. Of all patients considered to be candidates, $40 \%$ did not fulfil ASAS recommendations with respect to previous use of non-steroidal anti-inflammatory drugs (NSAIDs; at least two NSAIDs) or Bath Ankylosing Spondylitis Disease Activity Index ( $\geqslant 4$ ). Conversely, 36\% of patients who did not fulfil the NSAID or BASDAl recommendations were still considered to be candidates for TNFblocking treatment. Objective variables, such as $C$ reactive protein, erythrocyte sedimentation rate or magnetic resonance activity, were considered less important than disease activity in the decision on starting TNF-blocking drugs. The only important objective criterion was rapid radiographic progression. Conclusion: Rheumatologists wanted to initiate TNF-blocking drugs in roughly half of the patients with ankylosing spondylitis. However, there was a wide variation across countries and doctors. Rheumatologists considered both disease activity and severity to be determinants of starting TNF blockers, but their decision was often in disagreement with ASAS recommendations.
\end{abstract}

$\mathrm{N}$ on-steroidal anti-inflammatory drugs (NSAIDs), education, exercises and other modalities of physiotherapy are considered to be the cornerstone of treatment for patients with ankylosing spondylitis. ${ }^{12}$ Disease-modifying antirheumatic drugs (DMARDs) are considered second-line treatment, but conclusive evidence for the efficacy of these drugs with respect to spinal manifestations is still lacking. ${ }^{3}{ }^{4}$

The introduction of tumour necrosis factor (TNF)-blocking drugs has considerably changed the treatment options for patients with ankylosing spondylitis. Etanercept and infliximab seemed to be highly effective in improving signs and symptoms of ankylosing spondylitis, and are well tolerated. ${ }^{5-}$

${ }^{12}$ These drugs are currently registered for the reduction of signs and symptoms of ankylosing spondylitis; however, reimbursement guidelines or mechanisms have not been developed in many countries.

The question of which patients with ankylosing spondylitis are appropriate candidates for TNF-blocking treatment seems important in view of these drug costs and their yet unknown long-term advantages or disadvantages.

To help rheumatologists with this issue, the ASsessment in Ankylosing Spondylitis (ASAS) international working group has recently developed recommendations for the use of anti$\mathrm{TNF} \alpha$ treatment for patients with ankylosing spondylitis. ${ }^{13}$ These recommendations were developed by a review of published reports in combination with expert opinion, including a Delphi exercise, ${ }^{14}$ and a consensus meeting of the ASAS international working group. Following these recommendations, TNF-blocking agents should be considered in patients with mainly axial disease, who still have active disease defined as a Bath Ankylosing Spondylitis Disease Activity Index (BASDAI) score of at least 4 on a 0-10 scale, despite an adequate therapeutic trial of at least two NSAIDs at optimal doses for at least 3 months. In addition, a positive expert opinion to start treatment is also required. Before the publication, dissemination and implementation of these international ASAS recommendations, we explored in the international rheumatological community what type of patients with ankylosing spondylitis were considered to be suitable for treatment with TNF-blocking drugs. We examined a representative sample of rheumatologists from several countries in Europe, Canada, Mexico and Australia. A preliminary survey had been conducted in The Netherlands. ${ }^{15}$ The treating rheumatologists of patients

Abbreviations: ASAS, ASsessment in Ankylosing Spondylitis; BASDAl, Bath Ankylosing Spondylitis Disease Activity Index; DMARD, diseasemodifying antirheumatic drug; MRI, magnetic resonance imaging; NSAID, non-steroidal anti-inflammatory drug; TNF, tumour necrosis factor 
Table 1 Main demographic characteristics and disease history of patients with ankylosing spondylitis, with regard to country

\begin{tabular}{|c|c|c|c|c|c|c|c|c|c|}
\hline Country & $n$ & $\begin{array}{l}\text { Sex } \\
\text { (male, \%) }\end{array}$ & $\begin{array}{l}\text { Age } \\
\text { (years)* }\end{array}$ & $\begin{array}{l}\text { Disease } \\
\text { duration } \\
\text { since first } \\
\text { symptoms } \\
\text { (years)* }^{*}\end{array}$ & $\begin{array}{l}\text { Paid job } \\
\text { (yes, \%) }\end{array}$ & $\begin{array}{l}\text { Current } \\
\text { sick leave } \\
\text { (yes, \%) }\end{array}$ & $\begin{array}{l}\text { Inflammatory } \\
\text { bowel } \\
\text { disease } \\
\text { (yes, \%) }\end{array}$ & $\begin{array}{l}\text { Previous } \\
\text { treatment with } \\
\text { sulfasalazine } \\
\text { (yes, \%) }\end{array}$ & $\begin{array}{l}\text { Previous } \\
\text { treatment with } \\
\text { methotrexate } \\
\text { (yes, \%) }\end{array}$ \\
\hline Australia & 120 & 74 & $46(13)$ & $19(11)$ & 58 & 4 & 19 & 43 & 19 \\
\hline Belgium & 97 & 75 & 44 (14) & $16(12)$ & 57 & 22 & 7 & 29 & 11 \\
\hline Canada & 94 & 79 & $38(13)$ & $15(11)$ & 61 & 23 & 10 & 11 & 5 \\
\hline France & 137 & 55 & $41(14)$ & $13(11)$ & 59 & 17 & 10 & 38 & 5 \\
\hline Germany & 200 & 73 & 45 (14) & $16(11)$ & 67 & 12 & 6 & 32 & 15 \\
\hline Italy & 103 & 80 & $47(13)$ & $16(9)$ & 62 & 29 & 17 & 35 & 15 \\
\hline Mexico & 128 & 76 & $38(13)$ & $12(11)$ & 66 & 35 & 10 & 48 & 10 \\
\hline The Netherlands & 98 & 75 & $47(15)$ & $21(13)$ & 64 & 20 & 7 & 29 & 1 \\
\hline Spain & 183 & 78 & $47(14)$ & $18(12)$ & 64 & 42 & 5 & 37 & 9 \\
\hline UK & 47 & 77 & 48 (12) & $20(13)$ & 65 & 9 & 3 & 19 & 2 \\
\hline Total & 1207 & 74 & 44 (14) & $16(11)$ & 63 & 29 & 10 & 34 & 10 \\
\hline
\end{tabular}

*Values are mean (SD).

participating in an ongoing long-term observational cohort (Outcome in Ankylosing Spondylitis International Study) were asked whether they would start TNF-blocking treatment on their patients. Demographic, clinical and radiological data of these patients were compared with data of those who were and were not considered to be candidates for TNF-blocking treatment. In this survey, $30 \%$ of Dutch patients from the Outcome in Ankylosing Spondylitis International Study were considered to be candidates for TNF-blocking agents by their rheumatologists. Almost all parameters were worse for the candidates than for the non-candidates. Structural damage explained most variation in the practitioners' decision on whether or not to initiate anti-TNF treatment.

The first aim of this study was to obtain insight into the type of patients whom rheumatologists consider to be candidates for TNF blockers. We then analysed the decision whether to start TNF-blocking treatment for an individual patient with demographic characteristics, work status and information reflecting disease activity and disease severity. We also determined the actual proportion of patients with ankylosing spondylitis who were considered to be candidates for anti-TNF treatment in the community and to what extent these decisions were in agreement with the ASAS recommendations.

\section{METHODS}

\section{Rheumatologists}

ASAS members who were not associated with the development of the ASAS guidelines were invited to participate. Ten ASAS members from 10 different countries volunteered to act as national coordinators and to be responsible for the selection of rheumatologists and collection of data in their countries. The participating countries were: Australia, Belgium, Canada, France, Germany, Italy, Mexico, The Netherlands, Spain and the UK. Each country coordinator had to select rheumatologists who were considered to be experts in treating patients with ankylosing spondylitis and had ample experience with TNF-blocking agents in inflammatory rheumatic diseases. Most rheumatologists had experience with TNF-blocking drugs in ankylosing spondylitis in at least one clinical trial. These rheumatologists were unaware of the ASAS recommendations (unpublished at the time of study in 2003). The aim was to select 20 rheumatologists from each country. Rheumatologists were asked to evaluate 10 consecutive outpatients with a diagnosis of ankylosing spondylitis, and to determine whether they would initiate treatment with TNF blockers, assuming a certain risk-benefit profile for this treatment. This riskbenefit profile was defined as follows:

1. The treatment gives an improvement of at least $50 \%$ in at least $50 \%$ of the patients.

2. The drugs are available without limitation, and fully reimbursed.

3. There may be an unknown increased risk for (serious) infections, and little information is currently available on long-term safety.

The rheumatologists were asked to make the decision about the patient being a candidate for TNF-blocking drugs or not in the context of their normal routine practiceirrespective of whether this normal routine practice included

Table 2 Disease activity, function and anti-TNF indicated by the treating rheumatologist, with regard to country

\begin{tabular}{|c|c|c|c|c|c|c|c|c|c|}
\hline Country & n & BASDAl* $^{*}$ & BASFI* $^{*}$ & BASG* & $\begin{array}{l}\text { Night pain } \\
(0-10)^{*}\end{array}$ & $\begin{array}{l}\text { Patient global } \\
(0-10)^{*}\end{array}$ & $\begin{array}{l}\text { Raised ESR } \\
\text { (yes, \%) }\end{array}$ & $\begin{array}{l}\text { Raised CRP } \\
\text { (yes, \%) }\end{array}$ & $\begin{array}{l}\text { Start TNF } \\
\text { blockers (yes, } \\
\% \text { ) }\end{array}$ \\
\hline Australia & 120 & $5.5(2.3)$ & $5.5(2.7)$ & $5.8(2.5)$ & $4.7(2.8)$ & $5.7(2.5)$ & 39.2 & 55.4 & 78.3 \\
\hline Belgium & 97 & $4.3(2.4)$ & $4.2(2.7)$ & $5.2(2.3)$ & 3.9 (3.2) & 4.9 (2.6) & 40.3 & 58.0 & 56.7 \\
\hline Canada & 94 & $4.6(2.3)$ & $3.7(2.8)$ & $4.8(2.8)$ & 4.2 (2.7) & 4.5 (2.5) & 57.1 & 57.1 & 37.2 \\
\hline France & 137 & $4.8(1.2)$ & $3.8(2.7)$ & $5.4(2.5)$ & 4.3 (2.8) & $5.0(2.6)$ & 58.8 & 53.3 & 45.3 \\
\hline Germany & 200 & $4.2(2.1)$ & $4.1(2.6)$ & $5.3(2.4)$ & $4.5(2.8)$ & $5.0(2.8)$ & 55.2 & 58.9 & 49.0 \\
\hline Italy & 103 & $4.9(2.2)$ & $4.6(2.4)$ & $5.8(2.4)$ & $4.8(2.9)$ & $5.9(2.6)$ & 60.8 & 62.0 & 68.0 \\
\hline Mexico & 128 & 4.7 (2.7) & $4.5(3.1)$ & $5.5(3.0)$ & 4.5 (3.3) & 5.5 (2.9) & 50.0 & 45.7 & 41.4 \\
\hline The Netherlands & 98 & 4.1 (2.3) & $4.1(2.6)$ & $5.0(2.4)$ & 3.7 (2.9) & $4.3(2.8)$ & 40.5 & 48.1 & 40.8 \\
\hline Spain & 183 & $4.3(2.3)$ & $3.8(2.8)$ & $5.0(2.3)$ & $3.8(3.0)$ & $4.7(2.6)$ & 56.7 & 62.0 & 38.3 \\
\hline UK & 47 & $5.1(2.2)$ & $5.6(2.6)$ & 4.7 (2.5) & $5.0(2.9)$ & $5.5(2.8)$ & $7.7 \dagger$ & 42.9 & 38.3 \\
\hline Total & 1207 & $4.6(2.3)$ & $4.3(2.8)$ & $5.3(2.5)$ & 4.3 (2.9) & 5.1 (2.7) & 51.5 & 56.7 & 49.3 \\
\hline
\end{tabular}

BASDAI, Bath Ankylosing Spondylitis Disease Activity Index; BASFI, Bath Ankylosing Spondylitis Functional Index; BASG, Bath Ankylosing Spondylitis Global assessment of disease activity; CRP, C reactive protein; ESR, erythrocyte sedimentation rate; TNF, Tumour necrosis factor.

*Values are mean (SD).

†Data are available for only 13 patients. 
questionnaires or specific assessments-and not take the patient's ideas about anti-TNF treatment into consideration. They were also asked to list the information that formed the basis of their decision, by filling a checklist.

\section{Patients}

Consecutive patients with ankylosing spondylitis visiting their rheumatologist at an outpatient clinic visit were included in the study. Patients already treated with TNFblocking drugs were excluded.

Patients were first seen by their practitioner according to normal clinical routine. Immediately after the consultation, they were examined by a metrologist (another doctor or a research nurse) for full clinical assessment, and the patients completed questionnaires. The assessment profile included instruments selected by the ASAS working group as the core set to assess outcome in ankylosing spondylitis, ${ }^{16}{ }^{17}$ as well as other widely used instruments, such as BASDAI, ${ }^{18}$ swollen joint count (range 0-44) or tender enthesis count (range 032 ), and information on the disease severity, previous and ongoing treatments and work status.

\section{Statistical analysis}

Patients were divided into two groups: the "candidates", defined as patients in whom the treating rheumatologists wanted to start TNF blockers; and the "non-candidates", defined as patients in whom the treating rheumatologists did not wish to start TNF blockers (irrespective of the reason). The primary analysis was descriptive: means (standard deviation (SD)) and frequencies, stratified by country and TNF-blocking treatment options (candidate $v$ non-candidate), were calculated if appropriate. Univariate betweengroup differences were statistically tested using MannWhitney two-sample $U$ test, Kruskall-Wallis test or $\chi^{2}$ test (Fisher's exact test) if appropriate.

Odds ratios (ORs) were calculated to investigate the contribution of various features to the decision to start TNF blockers, and compare settings of candidates with the international ASAS recommendations. Profiles of patients were defined by the BASDAI score, and by NSAID failure. To investigate which variables independently contributed to the decision to judge a patient as a candidate for TNF-blocking treatment, a multivariate logistic regression analysis was carried out with the candidates or non-candidates as the dependent variable, and all disease characteristics, disease activity and disease severity measures as independent variables.

Table 3 Demographic characteristics, history and work status with regard to the willingness to treat with TNFblocking drugs

\begin{tabular}{llll}
\hline & \multicolumn{3}{l}{$\begin{array}{l}\text { Anti-TNF indicated by the treating } \\
\text { rheumatologist }\end{array}$} \\
\cline { 2 - 4 } & $\begin{array}{l}\text { Candidate } \\
\text { (n=595) }\end{array}$ & $\begin{array}{l}\text { Non- } \\
\text { candidate } \\
\text { (n=612) }\end{array}$ & p Value \\
\hline Sex (male, \%) & $73.0 \%$ & $74.4 \%$ & 0.6 \\
Age (mean (SD), years) & $43(12)$ & $45(15)$ & 0.08 \\
History of IBD (yes, \%) & $10.5 \%$ & $8.7 \%$ & 0.32 \\
Hip involvement (yes, \%) & $40.0 \%$ & $25.3 \%$ & $<0.001$ \\
Previous treatment: sulfasalazine & $63.5 \%$ & $36.5 \%$ & $<0.001$ \\
(yes, \%) & $67.8 \%$ & $32.2 \%$ & $<0.001$ \\
Previous treatment: methotrexate & $63 \%$ & $61.9 \%$ & 0.54 \\
(yes, \%) & $63.7 \%$ & $16.6 \%$ & 0.001 \\
\hline $\begin{array}{l}\text { Paid job (yes, \%) } \\
\text { Current sick leave (yes, \%) }\end{array}$ & $29.1 \%$ & & \\
\hline
\end{tabular}

$\mathrm{IBD}$, inflammatory bowel disease; TNF, tumour necrosis factor.
Table 4 Disease activity and function

\begin{tabular}{|c|c|c|c|}
\hline & \multicolumn{3}{|c|}{$\begin{array}{l}\text { Anti-TNF indicated by the treating } \\
\text { rheumatologist }\end{array}$} \\
\hline & $\begin{array}{l}\text { Candidate } \\
(\mathrm{n}=595)^{*}\end{array}$ & $\begin{array}{l}\text { Non- } \\
\text { candidate } \\
(\mathrm{n}=612)^{*}\end{array}$ & p Value \\
\hline BASDAI & $5.5(2.1)$ & $3.8(2.2)$ & $<0.001$ \\
\hline BASFI & $5.3(2.5)$ & $3.3(2.6)$ & $<0.001$ \\
\hline Global pain & $5.4(2.7)$ & 3.7 (2.6) & $<0.001$ \\
\hline Chest expansion $(\mathrm{cm})$ & $4.2(9.3)$ & $5.0(10.9)$ & $<0.001$ \\
\hline Cervical rotation (degree) & $49(60)$ & $57(52)$ & $<0.001$ \\
\hline Swollen joint & $1.9(3.9)$ & $0.7(2.0)$ & $<0.001$ \\
\hline Tender enthesis & $5.3(6.0)$ & $2.8(4.4)$ & $<0.001$ \\
\hline $\begin{array}{l}\text { ESR ( } \mathrm{mm} \text { at the end } \\
\text { of the first hour) }\end{array}$ & $33.5(24.1)$ & $18.8(16.1)$ & $<0.001$ \\
\hline $\mathrm{CRP}(\mathrm{mg} / \mathrm{l})$ & $19.9(21.8)$ & $9.8(9.8)$ & $<0.001$ \\
\hline \multicolumn{4}{|c|}{$\begin{array}{l}\text { BASDAI, Bath Ankylosing Spondylitis Disease Activity Index; BASFI, Bath } \\
\text { Ankylosing Spondylitis Functional Index; CRP, C reactive protein; ESR, } \\
\text { erythrocyte sedimentation rate; TNF, tumour necrosis factor. } \\
\text { *Values are mean (SD). }\end{array}$} \\
\hline
\end{tabular}

\section{RESULTS}

The 145 rheumatologists from 10 participating countries recruited a total of 1284 patients with ankylosing spondylitis. Data regarding the decision of the treating rheumatologists to initiate TNF-blocking treatment were available for 1207 patients, and these patients form the basis of this report. Overall, the rheumatologists indicated that they would start TNF blockers in $49.3 \%$ of the patients with ankylosing spondylitis.

High clinical disease activity, severe disease (including structural damage on spinal radiographs, loss of spinal mobility and loss of physical function), raised acute-phase reactants, lack of disease control by ongoing treatment, rapid functional decline and presence of peripheral arthritis (including hip involvement) were the reasons listed most often (in descending order) when considering the patient for TNF-blocking treatment. Rheumatologists rarely based their decision on disease activity on magnetic resonance imaging (MRI), recurrent infections, history of tuberculosis, comorbidity, high risk of adverse events in the patient and expected low compliance.

Tables 1 and 2 summarise the main characteristics of patients with ankylosing spondylitis. Important differences were observed with respect to the willingness to treat patients, ranging from $37.2 \%$ in Canada to $78.3 \%$ in Australia (table 2). On the basis of the BASDAI score and instruments proposed by the ASAS core set, Australian and UK patients had higher disease activity than patients from other countries. However, Australian and UK patients would have been treated with TNF blockers by their rheumatologists in different proportions (table 2).

Tables 3 and 4 compare the candidates and non-candidates with respect to demographic characteristics, history, work status, disease activity, functioning and spinal mobility. Demographic data were similar in both groups, with $72 \%$ men and a mean age of 44 years. Patients with a stated indication for TNF-blocking treatment tended more often to have a history of inflammatory bowel disease and hip involvement than the other patients (table 3 ). Candidate patients used DMARDs more often than non-candidates (previous DMARD use 89\% v 47\%; current DMARD use 62\% $v$ $42 \%)$ and more often reported sick leave.

All assessments of disease activity and severity (including patients' self-assessments), spinal mobility measures, joint counts, tender enthesis count, and acute-phase reactants scored on average higher in the candidate group, reaching significant differences (table 4). Thus, patients who were considered to be candidates for anti-TNF treatment by their 


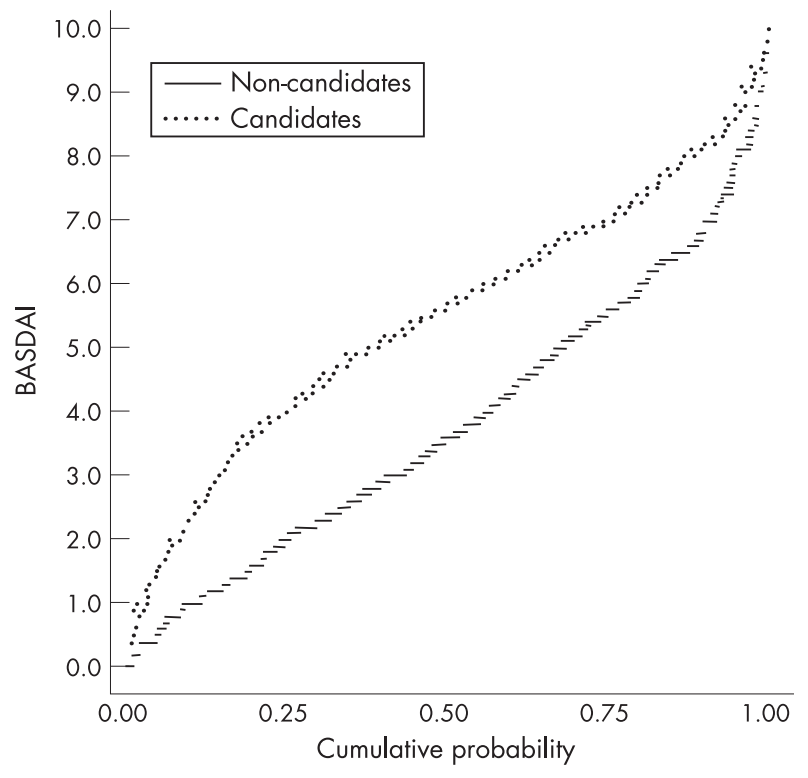

Figure 1 Cumulative probability plots of the distribution of the Bath Ankylosing Spondylitis Disease Activity Index (BASDAI) scores for the groups of candidate and non-candidate patients for treatment with tumour necrosis factor-blocking agents.

rheumatologist tended to have higher disease activity, higher levels of acute-phase reactants, worse spinal mobility, worse function, hip involvement more often and a higher prevalence of sick leave.

Figure 1 shows the cumulative probability plots of the distribution of the BASDAI scores for the groups of candidate and non-candidate patients. This plot shows that, although candidates have, on average, a higher BASDAI score than non-candidates, $40 \%$ of the patients who are not considered to be candidates by their rheumatologist still have a BASDAI score $>4$. By contrast, $25 \%$ of patients who are considered to be candidates have BASDAI score $<4$. The minimum and maximum levels of BASDAI scores observed in this study were similar for both candidates and non-candidates.

If compared with the ASAS recommendations, $40 \%$ of the patients considered to be candidates for TNF-blocking treatment by their rheumatologists did not fulfil ASAS recommendations for previous NSAID use (at least two NSAIDs) and BASDAI score ( $\geqslant 4$ ) (tables 5, 6). Conversely, $31 \%$ of patients who do not fulfil the NSAID or BASDAI recommendations are still considered to be candidates for TNF-blocking treatment. Interestingly, the OR for being a candidate fulfilling both the BASDAI and NSAID criteria of the ASAS recommendations was not higher than the OR for being a candidate fulfilling either the BASDAI or the NSAID criterion.

Table 7 shows to what extent variables that are considered objective, such as raised acute-phase reactions, and rapid structural progression and activity assessed by ultrasound, scintigraphy or MRI, may have influenced the decision of the rheumatologist-for example, if they failed the criterion of BASDAI score $\geqslant 4$. This is presented for all patients together, as well as stratified for BASDAI score $(\geqslant 4 v<4)$. All objective variables contributed at least to some extent to the decision to start TNF-blocking drugs $(\mathrm{OR}>1)$. Importantly, however, they contributed similarly, or sometimes even less $(\mathrm{C}$ reactive protein), in patients with a BASDAI score $<4$ compared with patients with a BASDAI score $\geqslant 4$. Rapid radiographic progression was the only factor that seemed to affect the decision to start TNF-blocking drugs in an expected direction: the OR for rapid radiographical progression was higher in patients with a BASDAI score $<4$ than in those with a BASDAI score $\geqslant 4$.

\section{DISCUSSION}

We showed that, on average, $49 \%$ of patients with ankylosing spondylitis attending the outpatient clinic of rheumatologists from 10 countries would have TNF-blocking treatment initiated according to their treating doctor. However, this varied from $38 \%$ to $78 \%$ of the patients among different

Table 5 Candidate and non-candidate settings compared with the ASAS recommendations

\begin{tabular}{|c|c|c|c|c|}
\hline & \multicolumn{4}{|c|}{ Anti-TNF indicated by the treating rheumatologist } \\
\hline & $\begin{array}{l}\text { Candidates, } \\
\mathrm{n}=595^{\star}\end{array}$ & $\begin{array}{l}\text { Non- } \\
\text { candidates, } \\
n=612^{*}\end{array}$ & $\begin{array}{l}\text { OR } \\
(95 \% \mathrm{Cl})\end{array}$ & p Value \\
\hline $\begin{array}{l}\text { ASAS recommendations fulfilled } \\
\text { ASAS recommendations not fulfilled } \\
\text { Total }\end{array}$ & $\begin{array}{l}357(60) \\
238(40) \\
595(100)\end{array}$ & $\begin{array}{l}188(31) \\
424(69) \\
612(100)\end{array}$ & $3.3(2.6$ to 4.3$)$ & $<0.001$ \\
\hline
\end{tabular}

ASAS, ASsessment in Ankylosing Spondylitis; TNF, tumour necrosis factor. *Values are $n(\%)$.

Table 6 Candidate and non-candidate settings compared with the components of the ASsessment in Ankylosing Spondylitis recommendations

\begin{tabular}{lllll}
\hline \multicolumn{5}{l}{ Anti-TNF indicated by the treating rheumatologist } \\
\cline { 2 - 5 } & $\begin{array}{l}\text { Candidate } \\
\text { (n=595) }\end{array}$ & $\begin{array}{l}\text { Non-candidate } \\
(\mathbf{n}=612)\end{array}$ & OR (95\%Cl) & p Value \\
\hline BASDAl $\geqslant 4$ & $456(77 \%)[62 \%]$ & $282(46 \%)[38 \%]$ & $3.8(2.9$ to 4.9$)$ & $<0.001$ \\
NSAIDs $\geqslant 2$ & $432(73 \%)[56 \%]$ & $345(56 \%)[44 \%]$ & $2.1(1.6$ to 2.7$)<0.001$ \\
BASDAl $\geqslant 4$ and NSAIDs $\geqslant 2$ & $357(60 \%)[66 \%]$ & $188(31 \%)[34 \%]$ & $3.4(2.6$ to 4.3$)<0.001$ \\
\hline
\end{tabular}

BASDAI, Bath Ankylosing Spondylitis Disease Activity Index; NSAID, non-steroidal anti-inflammatory drug; TNF, tumour necrosis factor.

Percentages in parentheses refer to the percentage of the candidates.

Percentages in square brackets refer to the percentage of patients fulfilling a certain criterion (eg, BASDAl score $\geqslant 4)$. 
Table 7 Influence of variables on opinions of rheumatologists for all patients together, stratified for the Bath Ankylosing Spondylitis Disease Activity Index criterion

\begin{tabular}{|c|c|c|c|c|}
\hline Variables & $\begin{array}{l}\text { n (available } \\
\text { data) }\end{array}$ & OR $(95 \% \mathrm{Cl})$ & $\begin{array}{l}\text { OR in patients with BASDAl score } \geqslant 4 \\
(95 \% \mathrm{Cl})(\mathrm{n})\end{array}$ & $\begin{array}{l}\text { OR in patients with BASDAl score } \\
<4(95 \% \mathrm{Cl})(\mathrm{n})\end{array}$ \\
\hline Raised ESR & 880 & 3.3 (2.5 to 4.5 ) & 2.9 (2.0 to 4.2$)(535)$ & $3.4(2.1$ to 5.6$)(345)$ \\
\hline Raised CRP & 793 & $3.8(2.8$ to 5.1$)$ & $3.9(2.7$ to 5.8$)(493)$ & $2.8(1.7$ to 4.8$)(300)$ \\
\hline Rapid radiographic progression & 476 & $8.6(5.5$ to 13.5$)$ & $7.8(4.2$ to 14.6$)(276)$ & $9.7(4.7$ to 19.7$)(200)$ \\
\hline Activity on MRI & 156 & $2.3(1.2$ to 4.5$)$ & $2.8(1.0$ to 7.7$)(96)$ & $1.5(0.5$ to 4.5$)(60)$ \\
\hline Activity on scintigraphy & 134 & $2.9(1.4$ to 5.9$)$ & $3.1(1.2$ to 7.8$)(95)$ & $2.4(0.6$ to 9.0$)(39)$ \\
\hline Activity on ultrasound & 80 & $2.9(0.9$ to 8.9$)$ & $3.4(0.7$ to 17.7$)(52)$ & $3.1(0.6$ to 16.9$)(28)$ \\
\hline
\end{tabular}

BASDAI, Bath Ankylosing Spondylitis Disease Activity Index; CRP, C reactive protein; ESR, erythrocyłe sedimentation rate; MRI, magnetic resonance imaging

countries. This study also shows that, in general, patients who are considered to be candidates for TNF-blocking treatment have a higher level of disease activity and more severe disease than those who are not considered to be candidates. But for individual patients, the patterns are less clear. Patients with high levels of disease activity by BASDAI are not always considered to be candidates by their doctors, and rheumatologists sometimes want to start TNF-blocking treatment in patients who currently have low levels of patient-reported disease activity, but who may, for example, have shown a high rate of radiographical progression.

One of the aims of this study was to get insight into what kind of patients with ankylosing spondylitis rheumatologists would like to treat with TNF blockers, before the publication, dissemination and implementation of the international ASAS consensus statement on the use of these drugs. ${ }^{13}$ The most important criteria of the international ASAS recommendations are a BASDAI score $\geqslant 4$, the failure of at least two NSAIDs and a positive expert opinion to start treatment. The expert opinion takes into account all clinical, laboratory and imaging information. In this study, rheumatologists seemed to initiate TNF-blocking treatment in patients with active and advanced disease, reflected by high BASDAI scores, high levels of acute-phase reactants and higher degrees of spinal and functional limitation. However, considerable discrepancies exist in opinions of rheumatologists across countries and doctors, irrespective of activity and severity of disease. These results confirm the need for recommendations to standardise management of patients with ankylosing spondylitis.

One of the major criteria defined in the ASAS recommendations for initiation of TNF-blocking agents is a BASDAI score of at least 4 on a $0-10$ scale. This cut-off criterion has proven to be robust and to predict, at a group level, patients with worse functional status and quality of life. ${ }^{19}$ This starting point for the decision to initiate TNF-blocking treatment meets a high level of face validity in the international ankylosing spondylitis field, because in our study $77 \%$ of the patients considered to be candidates by their rheumatologists had BASDAI scores $>4$, and $56 \%$ of the noncandidates had BASDAI scores $<4$. Moreover, other domains that were supposed to make up the expert opinion, and were considered to be "hard", such as high levels of acute-phase reactants or previous failure to NSAIDs, only moderately influenced the decision, with less weight compared with the criterion of BASDAI score $\geqslant 4$. However, the BASDAI criterion does not sufficiently explain by itself the rheumatologist's opinion. This indicates that the rheumatologist's opinion considerably adds to patient-reported disease activity rather than just reiterating that information.

Although the evidence that TNF-blocking treatment can retard radiographical progression is lacking, "rapid radiographic progression" seemed to be of importance in driving the rheumatologist's decision. Landewé et al ${ }^{15}$ observed this phenomenon in the preliminary survey conducted in The
Netherlands. In addition, we could not find firm evidence that other objective variables, such as $\mathrm{C}$ reactive protein level, erythrocyte sedimentation rate or activity on MRI, were considered to be more important than disease activity (BASDAI) in the decision to start TNF-blocking drugs. C reactive protein level and activity on MRI were even less contributory in explaining the decision to start TNF-blocking drugs in patients who did not fulfil the BASDAI criterion than in patients who did.

Rheumatologists do not seem to be influenced in their decision to start TNF-blocking treatment by previous NSAID use. In this study, exactly the same percentages of candidates and non-candidates fulfilled the BASDAI criterion solely and the combined criterion of BASDAI and NSAID. The results as described here should be taken into account in future updates of the international ASAS recommendations.

Our study has a few limitations. Firstly, this study was conducted in the early stages of anti-TNF treatment for patients with ankylosing spondylitis, and the level of experience of rheumatologists may not be similar in all instances. Secondly, although rheumatologists were asked to include patients in an unbiased manner (consecutive inclusion), it cannot be excluded that some selection towards a more active and severe disease course did occur. For example, patients with more active and severe disease, who visit the rheumatologist more often, have a higher prior probability of being included in this survey that spanned a limited period as compared with patients with inactive, quiet disease (sampling bias). Thirdly, rheumatologists had to make their decision under specific assumptions that may not entirely reflect reality. Nevertheless, the results highlight the willingness of the rheumatologists to start TNF-blocking drugs in the treatment of ankylosing spondylitis in a high percentage of patients; results also show that variation in this decision is quite large. This variation cannot be solely explained by differences in characteristics, and activity and severity of disease in patients. This observation indicates that recommendations on the initiation of TNF blockers might prove clinically useful. We intend to repeat this study after the implementation of the international ASAS recommendations in order to test whether these recommendations have contributed to the standardisation of TNF-blocking treatment.
Authors' affiliations
T Pham, Department of Rheumatology, Aix-Marseille II University, Conception Hospital, Marseille, France
$\mathbf{R}$ Landewé, $\mathbf{S}$ van der Linden, $\mathrm{D}$ van der Heijde, Department of Rheumatology, University Hospital, Maastricht, The Netherlands M Dougados, Rheumatology B Department, Cochin Hospital, René Descartes University, Paris, France
J Sieper, M Rudwaleit, Rheumatology, Department of Medicine I, Charité-Campus Benjamin Franklin, Berlin, Germany
J Braun, Rheumazentrum Ruhrgebiet, Herne, Germany
J Davis, Division of Rheumatology, University of California San
Francisco, San Francisco, California, USA 
E Collantes, Department of Rheumatology, Reina Sofia Hospital, Cordoba University, Cordoba, Spain

R Burgos-Vargas, Rheumatology Unit, Hospital General de Mexico, Mexico City, Mexico

J Edmonds, Department of Rheumatology, St George Hospital, Sydney, New South Wales, Australia

I Olivieri, Rheumatology Department of Lucania, San Carlo Hospital of Potenza, Potenza, Italy

I van der Horst-Bruinsma, Department of Rheumatology, VU University Medical Centre, Amsterdam, The Netherlands

H Mielants, Department of Rheumatology, University Hospital, Gent, Belgium

M Stone, University of Toronto, Toronto Western Hospital, Toronto, Ontario, Canada

P Emery, Department of Rheumatology \& Rehabilitation, University of Leeds, Leeds, UK

Competing interests: None declared.

\section{REFERENCES}

1 Dougados M, Dijkmans B, Khan M, Maksymowych W, van der Linden S, Brandt J. Conventional treatments for ankylosing spondylitis. Ann Rheum Dis 2002;61 (Suppl 3):iii40-50.

2 van der Linden S, van Tubergen A, Hidding A. Physiotherapy in ankylosing spondylitis: what is the evidence? Clin Exp Rheumatol 2002;20:S60-4.

3 Braun J, Sieper J. Therapy of ankylosing spondylitis and other spondyloarthritides: established medical treatment, anti-TNF-alpha therapy and other novel approaches. Arthritis Res 2002;4:307-21.

4 Leirisalo-Repo M. Prognosis, course of disease, and treatment of the spondyloarthropathies. Rheum Dis Clin North Am 1998;24:737-51, viii.

5 Brandt J, Haibel H, Sieper J, Reddig J, Braun J. Infliximab treatment of severe ankylosing spondylitis: one-year followup. Arthritis Rheum 2001;44:2936-7.

6 Van Den Bosch F, Kruithof E, Baeten D, Herssens A, de Keyser F, Mielants H, et al. Randomized double-blind comparison of chimeric monoclonal antibody to tumor necrosis factor alpha (infliximab) versus placebo in active spondylarthropathy. Arthritis Rheum 2002;46:755-65.

7 Kruithof E, Van den Bosch F, Baeten D, Herssens A, de Keyser F, Mielants H, et al. Repeated infusions of infliximab, a chimeric anti-TNFalpha monoclonal antibody, in patients with active spondyloarthropathy: one year follow up. Ann Rheum Dis 2002;61:207-12.
8 Breban M, Vignon E, Claudepierre P, Devauchelle D, Wendling E, Lepessailes $L$, et al. Efficacy of infliximab in refractory ankylosing spondylitis: results of a six-month open-label study. Rheumatology (Oxford) 2002:41:1280-5.

9 Braun J, Brandt J, Listing J, Zink A, Alten R, Golder W, et al. Treatment of active ankylosing spondylitis with infliximab: a randomised controlled multicentre trial. Lancet 2002;359:1 187-93.

10 Braun J, Brandt J, Listing J, Zink A, Alten R, Burmester G, et al. Long-term efficacy and safety of infliximab in the treatment of ankylosing spondylitis: an open, observational, extension study of a three-month, randomized, placebocontrolled trial. Arthritis Rheum 2003;48:2224-33.

11 Davis JC Jr, van der Heiide D, Braun J, Dougadas M, Cush J, Clegg D, et al Recombinant human tumor necrosis factor receptor (etanercept) for treating ankylosing spondylitis: a randomized, controlled trial. Arthritis Rheum 2003;48:3230-6.

12 Davis J Jr, Webb A, Lund S, Sack K. Results from an open-label extension study of etanercept in ankylosing spondylitis. Arthritis Rheum 2004;51:302-4.

13 Braun J, Pham T, Sieper J, Davis J, van der Linden S, Dougados M, et al. International ASAS consensus statement for the use of anti-tumour necrosis factor agents in patients with ankylosing spondylitis. Ann Rheum Dis 2003;62:817-24.

14 Pham T, van der Heijde D, Calin A, Khan MA, van der Linden S, Bellamy N, et al. Initiation of biological agents in patients with ankylosing spondylitis: results of a Delphi study by the ASAS Group. Ann Rheum Dis 2003;62:812-16.

15 Landewe R, Rump B, Van Der Heijde D, Van Der Linden S. Which patients with ankylosing spondylitis should be treated with tumour necrosis factor inhibiting therapy? A survey among Dutch rheumatologists. Ann Rheum Dis 2004:63:530-4.

16 van der Heijde D, Calin A, Dougados M, Khan MA, van der Linden S, Bellamy N. Selection of instruments in the core set for DC-ART, SMARD, physical therapy, and clinical record keeping in ankylosing spondylitis. Progress report of the ASAS Working Group. Assessments in Ankylosing Spondylitis. J Rheumatol 1999;26:951-4.

17 van der Heijde D, van der Linden S, Dougados M, Bellamy N, Russell AS, Edmonds J. Ankylosing spondylitis: plenary discussion and results of voting on selection of domains and some specific instruments. J Rheumatol 1999;26:1003-5.

18 Garrett S, Jenkinson T, Kennedy LG, Whitelock H, Gaisford P, Calin A. A new approach to defining disease status in ankylosing spondylitis: the Bath Ankylosing Spondylitis Disease Activity Index. J Rheumatol 1994:21:2286-91.

19 Barkham N, Kong KO, Fraser A, Tennant A, Emery P. The unmet need for effective therapy in ankylosing spondylitis. Arthritis Rheum 2003;48:S175. 